Персида С. ЛАЗАРЕВИЋ DI GIACOMO* Università degli Studi "G. d'Annunzio" Chieti-Pescara
Оригинални научни рад

Примљен: 21. 11. 2016.

Прихваћен: 10. 02. 2017.

\title{
ЕСЕЈИСТИЧКИ ДИСКУРС СРПСКЕ ПРОСВЕТИТЕЉСКЕ МРЕЖЕ
}

\begin{abstract}
У овом раду се на примеру дела Доситеја Обрадовића обрађује есејистички дискурс као средство формирања српске просветитељске мреже. Полазећи од резултата истраживања о језику и стилу есеја-писама у енглеској периодици и друштвеним интеракцијама академског света у XVIII столећу (Џонс 1997; Фицморис 2002; Фицморис 2007), анализира се онај „вид обраћања” (Иванић 2015) који карактерише стил Доситеја Обрадовића у другом делу Живота и прикљученија (1788), Собранију (1793), Мезимиу (1818) и приватној преписци. Управо тај вид обраћања, кроз разне изражајне конвенције, условљава да се постави претпоставка да се Доситеј у својим списима и писмима есејистичке садржине није обраћао „трговцима, свештеницима, сељанима, чобанима” већ кругу својих „содружника" и истомишљеника - српских културних радника с којима је те конвенције делио, као и бројне друге елементе, па тако у ствари настојао да формира просветитељску мрежу по моделу енглеских просветитеља и њихових есеја-писама.
\end{abstract}

Кључне речи: Доситеј Обрадовић, есејистички дискурс, српска просветитељска мрежа.

У овом раду се на примеру дела Доситеја Обрадовића обрађује есејистички дискурс као средство формирања српске просветитељске мреже. Референцијалну тачку за проучавање пружају истраживања које је начинила Сјузан Фицморис $(2002 ; 2007)$ у вези са периодичним есејем и мрежом културних заједница у Лондону XVIII столећа. Базу података која јој је послужила за истраживање сачињавају есеји који су објављивани у Лондону од 1670. до 1760. године и који објашњавају везе и односе између Џозефа Едисона, Ричарда Стила и других културних радника тог периода, кроз тзв. ,језичко понашање” („linguistic behaviour”, Бенет 1976). „Језичко понашање” је конкретизовано у чињеници да језички изрази могу да се појме и да се као повратна веза одразе на ум, те створе тиме комплексну и софистицирну мисао која заузврат може произвести језички израз. То би значило да говор рађа

\footnotetext{
*persida.lazarevic@gmail.com
} 
мисли, као што је природно и логична је нужност да се неке мисли манифестују само у језичком понашању:

Once thought has been linguistically expressed the expressions can be perceived and react back upon the mind, eventually creating more complex and sophisticated thought which in turn can be given linguistic expression. And so speech gives birth to thought. It seems also to be at least a fact of nature, and may even be a logical necessity, that certain thoughts can be manifested in linguistic behavior only. But both these propositions are compatible with the 'distinct existence' in every case of mental states and the linguistic behavior in which they may be manifested. (Армстронг 1971: 427-428)

Конкретно, кад је реч о „језичком понашању”, С. Фицморис разматра интерсубјективност стила који карактерише есеје типа The Spectator или The Tatler. Периодични есеј је био нови жанр у XVIII в. и потребно је нагласити да је заузимао стилски простор између писма и дијалога. У том смеру је С. Фицморис проучила есеје и писма разних културних група. Ради се о тзв. „друштвеним мрежама” (,social networks”) које су се формирале пре свега око Џозефа Едисона. Као кључни представник периодичног есеја, и заједно са Ричардом Стилом, Едисон је лансирао тада најуспешнији периодични часопис, The Spectator.

И управо у вези са чињеницом, коју истиче С. Фицморис, да се у свом облику есеј XVIII века налази, са стилске тачке гледишта, у простору између писма и дијалога, као одраз комуникације која се у есеју-писму изражава могуће је говорити о тзв. „дискурзивној заједници” („discourse community”). Реч је о термину који је формиран по аналогији према социолингвистичком термину „говорна заједница" (,speech community”)1, који одређује групе људи који деле заједничке језичке норме, карактеристике, и моделе; ти људи се слажу око тога који су њихови циљеви, па се говори о заједничкој интеркомуникацији међу члановима групе, а која служи да се пружи информација и да се створи повратна спрега. Постоји такође посебна лексика која карактерише те групе где се подразумева културни и социјални ниво чланова који појме садржај дискурса. Ради се дакле о заједници која дели конвенције и навике (Џонс, Свејлс 2002). Овај се термин често односи на чињеницу да разне академске заједнице користе у свом писању регистар који је разумљив дотичним члановима. Борг (2003: 398) сматра, међутим, да се дискурзивна заједница од говорне разликује управо у могућности избора и чланови одређене дискурзивне заједнице активно учествују у подели информација и постављању циљева који карактеришу целу групу; такве заједнице, које чак и не претпостављају да се чланови лично састају, одликују и дискусије које се обично фокусирају на употребу и анализу писане комуникације:

Unlike a speech community, membership of a discourse community is usually a matter of choice; unlike an interpretive community, members of a discourse community actively share goals and communicate with other members to pursue those goals. One additional element generally characterizes discussions of discourse communities: these discussions typically focus on the use and analysis of written communication (2003: 398).

\footnotetext{
${ }^{1}$ Односи се на групе које деле заједничке језичке, фонолошке, лексичке, морфолошке и синтакстичке норме и моделе (Гумперц 1962; Гумперц 1968; Лабов 1972).
} 
С. Фицморис је применила, дакле, овај концепт у анализи културних заједница енглеског XVIII столећа, с обзиром на то да је периодично писање морало да рачуна на интервале, комодитет конвенције, реторичке и стилске елементе, конвенције жанра, те је било потребно да се чланови те заједнице лако препознају.

Ако се има на уму да обраћање чланова дискурзивне заједнице има оквир есеја-писма, није онда необично да су теме унутар таквих есеја (тј. есеја-писама) садржавале изразе и реченице које се се упућивали адресату. ${ }^{2}$ У оваквим есејистичким облицима чланови дискурзивне заједнице користе дискурзивне маркере карактеристичне за енглески језик као: „I know”, „уоu know”, „I find”, , we see”, „I suppose”, заједно са модалним изразима, епистемским и атитудиналним глаголима: „hope”, „think”, „know”, „wish”, „desire”. Важно је истаћи да у овом смислу писма показују много чешћу употребу парентетичких белешки него што је то случај код есеја, али у есејима је много шира употреба таквих белешки него у писмима.

Намеће се питање да ли је таква врста интерсубјективне комуникативности постојала међу српским просветитељима? Односно, да ли и како се то одражавало на српску просветитељску средину у оном тренутку српске културне историје кад периодичних есеја није било, кад језичке конвенције нису претпостављале (и не претпостављају) интеркаларне коментаре карактеристичне за енглески језик. Овоме треба додати и повесну чињеницу да писменост међу Србима није била распрострањена као у Енглеској, коју су с правом звали ,reading nation”.

Познато је, међутим, да је на прелазу из XVIII у XIX век Доситеј оформио „дружество” и да је заједно са својим истомишљеницима намеравао да рашири просветитељске идеје међу Србима (Павић 1979: 103-119). Та плејада просветитеља је својом културном делатношћу задужила историју Срба: Павле Соларић (1779-1821), Викентије Ракић (1750-1818), Викентије Љуштина, Јоаким Вујић (1772-1847), Јован Дошеновић (1781-1813), Атанасије Стојковић (1773-1832), Глигорије Трлајић (1766-1811). Конкретно је Доситеј намеравао да са Соларићем оформи штампарију и школу негде међу Србима (в. Обрадовић 2008: 75).

Нашој књижевној историји такође је познато да је Доситеј у децембру 1784. доспео до Енглеске и ту је имао прилике да се упозна са енглеском, тачније шкотском културном заједницом у Лондону (Лазаревић Ди Ђакомо 2015): научио је довољно енглески језик да је могао да чита и преводи-прерађује енглеска дела, укључујући есеје и приче које је превео и адаптирао за српску публику и објавио (Јаварек 1955; Јаварек 1961; Јаварек 1978; Јаварек 2011; Лазаревић Ди Ђакомо 2015: 190-224). Знамо, дакле, да је енглеска културна традиција имала на Доситеја више утицаја од осталих европских средина и да је у Енглеској Доситеј достигао врхунац свог духовног развоја (Стојковић 1988: 70). И тек по одласку из Енглеске, из које је просто јурио

\footnotetext{
${ }^{2}$ Тако, нпр., есеји Вилијама Конгрива или Џона Драјдена имају облик писма па стога садрже и адресата.
} 
да би остварио оно што је наумио, Доситеј је објавио своја аутобиографска писма која сачињавају други део Живота и прикљученија (1788), затим Собpaније (1793) и напокон, после његове смрти је изашао и други део Собранија или Мезимац (1818).

Ако све ово имамо на уму, неизбежно је упитати се: коме се Доситеј у својим (аутобиографским) писмима и у својим есејима обраћа? Јер управо у овом смислу треба имати на уму онај, како каже Душан Иванић (2015), „вид обраћања” који карактерише стил Доситеја Обрадовића у другом делу Живота и прикљученија, у Собранију, у Мезимиу те приватној преписци. Тај вид обраћања, дакле, кроз разне изражајне конвенције, условљава да се постави претпоставка да се наш просветитељ у својим списима и писмима есејистичке садржине није обраћао „трговцима, свештеницима, сељанима, чобанима"; могло би се такође рећи да се Доситеј у својим есејима није обраћао ни младима. Односно, кад младима говори, као у предговору Баснама, или у понеком есеју, Доситеј је веома експлицитан, као нпр. у есеју „Шта ваља старији младима[а] да казују” (Собраније): „Сада расуди, благоразумни јуноше, што ласно можеш, за ово се не изискује велика наука - расуди колико је благополучан један човек који настоји у све време живота свога к овим блаженим достигнути својствам' [...]” (Обрадовић 2008б: 241); или: „О ти, српска јуносте! Внуши овоме што ћу ти сада рећи” (Исто: 242). Већ сам наслов, „Шта ваља старији младима[а] да казују”, указује нам, у суштини, да се Доситеј обраћа онима који ће васпитавати младе, тј. кругу својих савременика истомишљеника и будућих „содружника” - српских културних радника с којима је делио или намеравао да подели конвенције и бројне друге елементе, па је тако у ствари настојао да формира просветитељску мрежу по моделу енглеских просветитеља и њихових есеја-писама.

То обраћање почиње већ у аутобиографским писмима која, заједно са приватним писмима, формирају концептуални оквир за Собраније. И та писма-есеје и есеје-писма треба имати на уму кад је реч о Доситејевим изражајним, формалним и садржинским намерама. Ако је С. Фицморис закључила да је енглеске културне заједнице карактерисао посебан вид обраћања који је био присутан у есејима који су имали тон писама, па се тако формирала енглеска просветитељска мрежа XVIII века, не можемо занемарити оно што нам Мирјана Д. Стефановић (2009: 93-94) наглашава, а тј. да су популарни есеји из енглеских часописа „постали узор и српском водећем есејисти из доба просветитељства, Доситеју, који је из њих преузимао израз и тон урбаног менталитета, идеју космополитизма и толеранције, као и теме пријатељства.” М. Д. Стефановић (Исто: 94) додаје да је есеј постао Доситејев основни жанр, „и то у једној од енглеских варијаната, монолошком моралном есеју”. А кад је пак реч о писму, ауторка истиче:

$[\ldots]$ писмо испољава оно што је водећа вредност овог века - пријатељство, које може да постоји само у комуникацији с неким, у саопштавању које радошћу испуњава и оног који пише и особу којој се нешто саопштава, само њој за душу. Верујући да се писмом и на даљину може пријатељевати, испредају се писма у праве есеје аутобиографског исказа (Исто: 170). 
Иако нема сумње да, како каже Д. Иванић „Доситејева ријеч рачуна на широку рецепцију: она се тиче свих, пастира и земљодјелаца, трговаца и земљопосједника, учених људи и оних који сједе на царским престолима, до младог читаоца и српске јуности, како је говорио у предговору Баснама" (2015: 49), сумњамо, међутим, да се у својим аутобиографским писмима и Собранију свима њима, пре свега пастирима и земљоделцима, Доситеј директно обраћао. До Доситеја код Срба није било писмених људи, односно проценат писмености је био веома низак и ограничавао се на манастирску писменост. Ко је дакле читао Доситејева дела, ако не пре свега његови содружници? Та „широка рецепција” о којој говори Д. Иванић и која се састојала од „свих који знају читати и писати” (Исто: 24) могла је да се оствари тек путем просветитељске делатности Доситејевих истомишљеника, заједничким напором васпитавања и културног уздизања народа. Овоме треба додати и чињеницу да кад је реч о аутобиографским писмима, како каже Ана Ћосић Вукић (2000: 401), она „немају лични тон, осим једанаестог писма”, а с обзиром на то да је Доситеј своје књиге слао читаоцима Србима по целој Европи, с тог је становишта „целокупно дело Доситеја Обрадовића у једном широком и аутентичном значењу епистоларног карактера" (Исто: 407).

Ако се Доситеј у својим аутобиографским писмима и есејима из Собранија и Мезимца обраћа себи савременим и будућим српским културним радницима, како претпостављамо, онда се мора размотрити да ли и које дискурзивне маркере користи и како се уопште језички понашају Доситеј и његови истомишљеници. Српском језику не одговарају у потпуности интеркаларни коментари енглеског типа; но и поред тога, интерсубјективност је више него очигледна у Доситејевим списима која су овом приликом узета у обзир. Интерсубјективност је термин који се користи у филозофији, антропологији, социологији и психологији да би се представили односи међу људима, и тим се термином наглашава друштвеност људског бића (Гилеспи, Корниш 2010). Тај концепт претпоставља да се људи међу собом слажу у вези са неком темом, значењем, стањем, да више од две особе међу собом деле то стање. Ради се о свакодневном здраворазумском опхођењу које претпоставља заједничке конвенције, а што се у Енглеској у доба Доситеја садржавало у појму соттоп sense и што је као такво и остало и карактерише заједнице Северне Европе у свакодневном друштвеном и културном животу. Та свест о интерсубјективности (Џонс 1997: 33-35) претпоставља заједничку и међусобну поделу културних вредности, регистра, конвенција и концепција, и која је суштинска за обликовање наших идеја и односа те у том процесу језик и дискурс заузимају значајну улогу јер су заједнички, а не приватни фактор. И управо као заједнички, занимљиво је видети да појединци дискурзивне заједнице уносе своје личне маркере изражавања.

Ако знамо да common sense код Доситеја добија облик и садржај „здравог разума” и „опште ползе”, увидећемо да интерсубјективност његових аутобиографских писама наглашава управо његов однос према другима, као и да његови есеји добијају облик писама. А интерсубјективне и интеркаларне енглеске маркере замењује Доситејев начин обраћања у писмима. Па иако 
писмо само по себи захтева одговор (адресата коме је упућено), са Доситејевим аутобиографским писмима то није случај јер она не описују само његова путовања, већ изражавају његове ставове. Уочавамо тако писма која представљају варијације, пре свега формалности типа: „Пречестњејши господине! љубемејши и дражајши мој!”, „љубими мој!” „Дражајши господине мој!”. Такво слично обраћање свом „господину” видимо у писмима Доситејевог грчког пријатеља из Лондона Совера Лузињана (в. Лазаревић Ди Ђакомо 2015: 61-76) која је Лузињан објавио исте године (Лузињан 1788) и која су била упућена стварном адресату, историјској личности, Вилијаму Фордајсу (1724-1792), Доситејевом патрону у Лондону (Обрадовић 2007: 148). Но за разлику од Лузињановог формалног и репетитивног „Dear Sir”, Доситеј у својим писмима прелази у једном тренутку на једно далеко присније „друже”: „Дражајши сердечни друже!” или „Љубими предраги друже!”. Осим тога, то Доситејево „Љубими мој”, не тако ретко се појављује и као интеркаларни коментар, као „маркер” Доситејевог стилског израза као у следећим примерима: „Ево, љубими мој, почетак, могу рећи, мојега благополученија на овоме свету и моје давно желајеме науке” (Исто: 99); „За једно писмо, љубими мој, мислим да је већ доста написато” (Исто: 108); „Сад реци, љубими мој, но по души и совести реци, нисам ли ја у оно шест година у Бечу благополучан био?” (Исто: 119).

Овакви стилски маркери којима се манифестује културна реципрочност и интерсубјективност српске просветитељске дискурзивне заједнице, видни су и у првом и другом делу Собранија, у Доситејевом одабиру списа есејистичког типа које је представио српској читалачкој публици. Тако и оно „по мојем обичају” из приче „Гора вежества и истине”, а која је у ствари прича енглеске списатељице Ане Летише Барболд (1743-1825), која је и сама била део Ричардсонове културне мреже (Монтини 2014: 176; Лазаревић Ди Ђакомо 2015: 210-213) и као таква је поштовала конвенцију енглеске дискурзивне заједнице. ${ }^{3}$ Тај одломак, дакле, гласи:

У један јесењи но ведри дан поподне (каже нам неки љубитељ муса̂) пођем ја, по мојем обичају, при подножју једне високе горе, около неке плодоносне долине про[х]одати се за упокојити ум мој од преполудневнега читања и, у исто време, позабавити га с тијим размишљенијем они[х] полезни[х] вешти које сам читао и научио (Обрадовић 2008б: 12).

\section{Исто тако читамо и у есеју „О несогласију наши[х] желанија”:}

Јеси ли се ти други, пак, заљубио у науку и мудрост; јеси ли зажелио знати шта су гречески и латински и после њи[х] други[х] народа учени људи знали, ваља да томе послу све своје младости време предадеш и посветиш и тако с постојаним трудом и с временом получићеш шта желиш.

„Но, какво ја награжденије од мојега труда имам?” питаш. Ако то не знаш, сам си крив што си изабрао оно што није за тебе. Нејмаш ли познање многи[х] предивни[х] вешти, соопштеније и сожителство најкранији[х] умова, који на небу разума како звезде сијају? Нејмаш ли једну прост[р]аноразумителну душу, очишћену од простачки[х]

\footnotetext{
${ }^{3}$ Ана Летиша Барболд је издала Ричардсонову кореспонденцију (1804) у коју је, међутим, унела доста измена. Но и поред тога, њено уређивање тих писама потврђује њено познавање друштвених и језичких конвенција енглеске просветитељске мреже (Паландер-Колин 2010).
} 
плашњâ, сумња̂, и сујевјерја̂; душу способну дела мудрости божје разумевати и другима изјашњавати, ум богат, цветућ, благоустројен, к могућему совершенству доведен, преисполњен с неисточнимими сокровиштами благородни[х] забава и размишљења, с непрестаним пролећем нови[х] поњатија, са совесним умеренијем и чувствованијем достојинства овога рода богаства? (2008б: 22-23; наш курзив).

И у овом случају се не треба зачудити, ако знамо да је Доситеј ову приповест преузео од списатељице Ане Ејкин (1743-1825) (Јаварек 1955: 442; в. Лазаревић Ди Ђакомо 2015: 209), која је била део културног кружока Семјуела Џонсона, али и Семјуела Ричардсона, који је и сам у својим епистоларним романима, у интерсубјективној комуникацији са читаоцима и истомишљеницима, водио читаоце ка моралној регенерацији (Кејмер 1992; Вајмен 2007).

Оваква интерсубјективна комуникација је видна и у есеју „О љубови живота”, у Мезимиу, где уочавамо да се Доситеј обраћа „љубазној браћи”:

Но, ако ми наше именије и благополучије, која смо ми само чрез богодана и богодарована нам спосопства получили и придобили, на славу божју, а то јест на ползу општества и рода нашега (зашто, не варајмо себе, бог друге славе од нас не потребује!); ако ми, љубезна братије, са свим, с чим и с коликим можемо, општему добру не помажемо, ми смо слаби људи, ми смо недостојни рода нашега и живота, ми смо љуто неблагодарни и зли синови небеснога вечнога благодетеља и оца, од кога имамо све што имамо и који нам je, како год живот, тако и све што имамо, на кратко време дао, само да нас позна какви смо људи и којега смо духа и чији хоћемо да смо синови, света или помрчине; [...] (Обрадовић 2008б: 230; наш курзив).

У тринаестој глави Мезимщ̧а пак у есеју „О учењу историје”, Доситеј помиње експлицитно имена својих содружника, Глигорија Трлајића и Атанасија Стојковића:

Ја признајем по совесности и чистосердечно да се находим у овоме послу не много даље него Саул међу пророци, али само доброжелателно напомињем, и као с прстом показујем, да у своје време који наш Терлајич, или Стојкович, или благосердечножелателни Арађанин са својим живописним пером, као прави и као један од дванадесет верховни[х] пророка, ову преполезну материју пространије и оштроумније нашим једноплементим љубочитатељем предложити соизволи (Исто: 245).

Тако уосталом и у писму Димитрију Јосифовићу: „Хвала богу, имамо у недри људе, Рајича и Терлајича, њима та чест и слава принадлежи” (Обрадовић 2008а: 59).

А у закључном есеју другог дела Собранија који је насловљен „Како нека противоречија могу у исто време истини согласна бити”, очигледно је комуницирање међу истомишљеницима, српским просветитељима:

Посидип гледа све с ружне стране, и све му је накриво, и има право. А добри Митродор сматра све с лепше стране и све му је добро; и по мојеј памети (ако је слободно казати) има правије, барем је овога право пробиточно и весело. При том, нека каже ко што мисли, ја сумњам да је и онај баш тако мислио, како што је писао. [...]

Сада већ свака шала на страну. Воопште человеческом роду полезније је да је благополучан, него високоучен (Обрадовић 2008б: 268).

Заокружиће ове есеје Доситејева приватна писма, као оно нпр. Соларићу од 5. јуна 1804, у коме, баш као и у последњим редовима Живота и прикљу- 
ченија (Обрадовић 2007: 154-155) комбинује и алтернира форму учтивости са неформалним и присним ти, чиме као да надомешћује оно неутрално енглеско уои које недостаје српском језику и које Доситеј овако изражава:

Љубезни Господин Соларић!

Здравствуј ми!

Колико Вам мање пишем, толико Вас више и сердечније љубим да сте Ви такови к мени и да Вам свако вече пада на ум моја песна: „Море ђаче, нешто врана гаче!”

Знате да без потребе ласно се писати не накањујем, али, кад би[х] Вам и из љубови сердца писао, имао би[х] шта, зашто би[х] све то више материје находио, а к томе сад времена не притиче, зашто све мислим о различним материјама вторе почете части „Собранија вешти”, од који[х] сам јуче девету совершио главу. Ја себи ласкам да ће Вам ово сочиненије повољно бити. Но кад увидите чадо, познаћете је ли оцу подобно или, залуду, са̂м себи похлепствујем. [...] Ако што и буде без соли и вкуса, знај добро, пријане, да ће сва на тебе кривица пасти, зашто ћу ја сваком казати да ме је мој Соларић на ту навукао безделицу, потежући ме за уши као младо прасе у бостан диња и као старо магаре на младу салату. Ево ти овде чисто исповедам, нудер сад гледај како ћеш се опрати. Да си јошт' у Падуји, ласно би било, кроз коју чиста протиче река, а у Венецији доста ће ти мучно бити, ибо саิм видиш какови су канали. Ево ти ја каза[х] као добар пријан, јер не би[х] рад да те беда изненада нађе и да ти точак у верло дубоки западне вагаш.

$[\ldots]$

Здравствуј ми, Соларићу драги, и настој за општеполезно предузето дело (Обрадовић 2008а: 67-68; наш курзив).

Овај се интерсубјективни дискурс Доситејевих есеја и писама одражава неизбежно у томе што су туђа дела била заједничка, тако да је и Соларићево Земљьописаније, нпр., било „наше”, како је писао Петру I Петровићу Његошу: „Ја једва чекам да се наше преизрјадно 'Всеопште земљописаније' у Венецији соверши [...]" (Исто: 75).

Доситејева „надежда” је ишла у правцу „здравог разума” и „опште ползе”, управо како су напори енглеских културних радника ишли у правцу „common sense-a”. Доситеј је у Енглеској схватио шта му је радити, и на томе је делао, тј. на формирању српске просветитељске мреже свим својим снагама, пером пре свега.

\section{ЛИТЕРАТУРА}

Армстронг 1971: D. M. Armstrong, Meaning and Communication, Philosophical Review, 80, 427-447.

Бенет 1976: J. Bennet, Linguistic Behaviour, Cambridge: Cambridge University Press.

Борг 2003: E. Borg, Discourse community, ELT Journal, 57/4: 398-400.

Вајмен 2007: S. E. Whyman, Letter Writing and the Rise of the Novel: The Epistolary Literacy of Jane Johnson and Samuel Richardson, Huntington Library Quarterly, 70, 4, 577-606.

Гилеспи, Корниш 2010: A. Gillespie, F. Cornish, Intersubjectivity: Towards a Dialogical Analysis, Journal for the Theory of Social Behaviour, 40/1, 19-46. 
Гумперц 1962: J. J. Gumperz, Types of linguistic communities, Anthropological Linguistics, 4/1, 28-40.

Гумперц 1968: J. J. Gumperz, The speech community, in: A. Duranti (ed.), Linguistic Anthropology: A Reader, Oxford: Blackwell, 43-52.

Иванић 2015: Д. Иванић, Зашто читати Доситеја, Београд: Задужбина Доситеј Обрадовић.

Јаварек 1955: V. Javarek, Essays Translated from English in the „Sobranije” of Dositej Obradović, The Slavonic and East European Review, XXXIII/81, June, 437-456.

Јаварек 1961: В. Јаварек, Доситејево интересовање за дела енглеских моралиста XVII и XVIII века, Ковчежић. Прилози и грађа о Доситеју и Вуку, IV, 5-15.

Јаварек 1978: В. Јаварек, Огледи преведени са енглеског у „Собранију” Доситеја Обрадовића, Зборник Матице српске за књижевност и језик, XXVI/3, 471-488.

Јаварек 2011: В. Јаварек, Доситејево интересовање за дела енглеских моралиста XVII и XVIII века (Гледано кроз његове Совјете здраваго разума), у: Д. Иванић (прир.), Доситеј и Европа, Београд: Задужбина „Доситеј Обрадовић", 91-101.

Кејмер 1992: T. Keymer, Richardson's Clarissa and the Eighteenth-Century Reader, Cambridge: Cambridge University Press.

Лабов 1972: W. Labov, Sociolinguistic patterns, Philadelphia: University of Pennsylvania Press.

Лазаревић Ди Ђакомо 2015: П. Лазаревић Ди Ђакомо, У Доситејевом кругу. Доситеј Обрадовић и шкотско просветитељство, Београд: Задужбина Доситеј Обрадовић.

Лузињан 1788: [S. Lusignan], A Series of Letters. Addressed to Sir William Fordyce, M. D. F. R. S. [...], London: Printed for the AUTHOR.

Монтини 2014: D. Montini, Language and Letters in Samuel Richardson's Networks, Journal of Early Modern Studies, 3, 173-198.

Обрадовић 2007: Д. Обрадовић, Писмо Харалампију: Живот и прикљученија, књига прва, (прир.) М. Д. Стефановић, Београд: Задужбина Доситеј Обрадовић.

Обрадовић 2008а: Д. Обрадовић, Песме: Писма: Документи, књига шеста, (прир.) М. Д. Стефановић, Београд: Задужбина Доситеј Обрадовић.

Обрадовић 2008б: Д. Обрадовић, Собраније разних наравоучителних вештеј: Мезимаи, књига четврта, (прир.) М. Д. Стефановић, Београд: Задужбина Доситеј Обрадовић.

Павић 1979: М. Павић, Историја српске књижевности класищизма и предромантизма. Класицизам, Београд: Нолит.

Паландер-Колин 2010: M. Palander-Collin, Correspondence, y: A. H. Jucker, I. Taavitsainen (eds), Historical pragmatics, Berlin: De Gruyter Mouton, 651-677.

Свејлс 1990: J. M. Swales, Genre analysis: English in academic and research settings, Cambridge: Cambridge University Press. 
Стефановић 2009: М. Д. Стефановић, Лексикон српског просветитељства, Београд: Службени гласник.

Стојковић 1988: A. В. K. Stojković, Životni put Dositeja Obradovića: Od šegrta i kaluđera do filozofa prosvetitelja i Karađorđevog ministra prosvete, Beograd: Beletra.

Ћосић Вукић 2000: А. Ћосић Вукић, Епистоларни израз у делу Доситеја Обрадовића, у: Живот и дело Доситеја Обрадовића: зборник радова, Београд: Завод за уџбенике и наставна средства, 395-408.

Фицморис 2002: S. Fitzmaurice, Politeness and modal meaning in the construction of humiliative discourse in an early eighteenth-century network of patron-client relationships, English Language and Linguistics, 6/2, November, 239-265.

Фицморис 2007: S. Fitzmaurice, The world of the periodical essay: Social networks and discourse communities in eighteenth-century London, March, Historical Sociolinguistics and Sociohistorical Linguistics, 7: http://www. hum2.leidenuniv.nl/hsl_shl/periodical\%20essay.htm. 29.09.2016.

Џонс 1997: A. M. Johns, Text, Role, and Context: Developing Academic Literacies, New York: Cambridge University Press.

Џонс, Свејлс 2002: А. M. Johns, J. M. Swales, Literacy and disciplinary perspectives: opening and closing perspectives, Journal of English for Academic Purposes 1, 13-28.

Persida S. Lazarević Di Giacomo

\section{ESSAYISTIC DISCOURSE AND THE SERBIAN ENLIGHTENMENT NETWORK}

(Summary)

Using the works of Dositej Obradović this paper analyses the way in which essayistic discourse was used to form the Serbian Enlightenment network. Starting with the results of research on the language and style of the essay-letters in the English periodicals and social interactions of the academic world in the 18 th century England (Johns 1997; Fitzmaurice 2002; Fitzmaurice 2007), consideration is then given in the "kind of speech" (Ivanić 2015) that characterizes the style of Dositej Obradović in The Life and Adventures (1788), Sobranije (1793), Mezimac (1818) as well as in his private correspondence. The expressive conventions used by Obradović in this essayistic discourse show that he was not talking to "merchants, priests, peasants, shepherds" but to rather his collaborators - Serbian cultural workers with whom he shared not only these expressive conventions but also many other elements. It was through this essayistic discourse, modeled on that of the English Enlightenment figures and their essay-letters that Obradović succeeded in forming a network for the diffusion of Enlightenment thought among his own people. 